\title{
Charcot-Marie-Tooth disease type 2B5
}

INSERM

\section{Source}

INSERM. (1999). Orphanet: an online rare disease and orphan drug data base. CharcotMarie-Tooth disease type 2B5. ORPHA:228374

Charcot-Marie-T ooth disease type 2B5 is a rare axonal hereditary motor and sensory neuropathy characterized by infantile onset of slowly progressive distal motor weakness and atrophy (more severe in legs and moderate in arms) with mildly delayed motor development, hypotonia, and distal sensory impairment of all sensory modalities. 